\title{
The Effectiveness of Ethanol Extract of Red Betel Leaf (Piper crocatum) Againts Mortality of Boophilus microplus Larvae In Vitro
}

\section{Efektivitas Ekstrak Etanol Daun Sirih Merah (Piper crocatum) Terhadap Mortalitas Larva Boophilus microplus Secara In Vitro}

\author{
${ }^{1)}$ Meta Aprilia, ${ }^{2)}$ Poedji Hastutiek, ${ }^{3)}$ Rochmah Kurnijasanti, ${ }^{2}$ Lucia Tri Suwanti, ${ }^{3)}$ Moh \\ Sukmanadi, ${ }^{2)}$ Endang Suprihati \\ ${ }^{1)}$ Student, Faculty of Veterinary Medicine, Universitas Airlangga. \\ ${ }^{2}$ Department of Veterinary Parasitology, Faculty of Veterinary Medicine, Universitas Airlangga. \\ ${ }^{3)}$ Department of Basic Veterinary Medicine, Faculty of Veterinary Medicine, Universitas Airlangga. \\ Received: 25-02-2019, Accepted: 10-03-2019, Published Online: 19-03-2019
}

\begin{abstract}
The aims of this study is to know the effectiveness of ethanol extract of red betel leaf (Piper crocatum) against mortality of Boophilus microplus Larvae in vitro, as well as knowing lethal concentration $50\left(\mathrm{LC}_{50}\right)$ and lethal concentration $90\left(\mathrm{LC}_{90}\right)$. Method that used in the research was completely randomized design. There were five treatments and each treatment was done in five replications. This research used ten Boophilus microplus larvae in each treatment for all replication. The observation and recording of mortality was done at 1, 2, 3, 4, and 5 hours. Boophilus microplus larvae were declared dead if there was no movement. The obtained data was analyzed using ANOVA factorial. The result of this research show that ethanol extract of red betel leaf (Piper crocatum) has effectiveness against mortality of Boophlius microplus larvae in vitro. In the extract $10 \%$ concentration, there is effectiveness that almost the same as Noticks. The higher concentration of the extract, the higher the effectiveness against mortality lavae.In probit analysis show that $\mathrm{LC}_{50}$ achieved by concentration $5,4 \%$ or $2.700 \mathrm{mg} / 5 \mathrm{Oml}$ and $\mathrm{LC}_{90}$ achieved by concentration $11,3 \%$ or $5.650 \mathrm{mg} / 5 \mathrm{oml}$.
\end{abstract}

Keywords: Red Betel Leaf, Mortality, Boophilus microplus Larvae

\section{Pendahuluan}

hingga saat ini kegiatan pengembangan ternak di Indonesia belum dapat mencapai titik yang diharapkan, kondisi ini terjadi karena adanya beberapa faktor penghambat (Bamuallim, 2007), salah satu faktor penghambat tersebut salah satunya mengenai masalah kesehatan ternak. Masalah kesehatan ternak di Indonesia masih menjadi satu bahasan yang hingga saat ini belum dapat diselesaikan secara menyeluruh, salah satu masalah kesehatan ternak yang masih dianggap serius adalah akibat serangan caplak. Indonesia yang memiliki iklim tropis menjadi faktor penunjang pertumbuhan caplak yang sangat cepat. Salah satu spesies caplak yang sering dijumpai keberadaannya di Indonesia adalah caplak Boophilus microplus. Caplak tersebut memiliki dua fase selama kehidupannya yakni fase parasitik dimulai dari larva hingga dewasa dan fase non parasitik dimulai dari telur hingga larva (Verdonck, 2013). Kerugian ekonomis terjadi karena caplak menghisap darah $B$. microplus dapat meghisap darah sehingga dapat menyebabkan anemia (Jongejan dan Uilenberg, 2004). Seekor caplak dapat menghisap darah sebanyak $0,3 \mathrm{ml}$ sehari sehingga dapat mengganggu pertumbuhan, menimbulkan kegatalan, bahkan dapat merusak kulit karena menimbulkan jaringan nekrotik pada kulit yang mengakibatkan harga kulit ternak turun (Wahyuwardani, 1995) selain itu caplak B. microplus merupakan vektor dari penyakit babesiosis dan anaplasmosis yang banyak menyebabkan kematian pada ternak (Boka et al., 2017)

Banyaknya masalah yang ditimbulkan akibat serangan caplak B. microplus memerlukan penanganan yang serius. Penanganan kasus caplak di peternakan yang hingga saat ini masih sering dilakukan adalah dengan menggunakan bahan kimia yang memiliki efek sebagai insektisida, namun penggunaan insektisida sintetik dapat menimbulkan dampak negatif seperti berkembangnya ras resisten, terbunuhnya predator alami hama, keracunan pada 
manusia dan hewan ternak penyebab kanker, residu pada daging dan susu, dan pencemaran lingkungan (Wardhana dan Diana, 2014). Banyaknya dampak negatif yang ditimbulkan menyebabkan perlu adanya alternatif lain. Insektisida nabati yang berasal dari tanaman dapat menjadi salah satu pilihan yang tepat. Daun sirih merah (Piper crocatum) menjadi salah satu tanaman yang memiliki banyak manfaat salah satunya dapat digunakan sebagai

kandungan flavonoid dari daun sirih merah memiliki kadar lebih tinggi dari daun sirih hijau, sedangkan menurut penelitian yang telah dilakukan (Neldawati dan Gusnedi, 2013) kandungan sirih merah berupa flavonoid yang terbagi atas flavon dan flavonol memiliki jumlah lebih tinggi dibanding kadar flavonoid daun sirsak, daun katuk, dan daun ekor naga. Penelitian sebelumnya yang dilakukan oleh Fatrowie (2015) menggunakan tanaman sirih hijau (Piper betle) terbukti efektif sebagai larvasida. Kesamaan kandungan yang ada di dalam daun $P$. crocatum dan $P$. betle menjadi dasar acuan bahwa daun sirih merah dapat digunakan sebagai larvasida terhadap Boophilus microplus, karena penelitian daun sirih merah sebagai insektisida ataupun larvasida masih sangat jarang dilakukan.

\section{Materi dan Metode Penelitian}

Bahan yang digunakan dalam penelitian ini adalah Simplisia daun sirih merah, aquadest, etanol $96 \%$ tekhnik, noticks mengandung $10 \mathrm{~g}$ coumaphos, Tween 8o.

Alat-alat yang digunakan dalam penelitian ini adalah kain kasa, jarum penusuk tumpul, timbangan digital, pipet, spuit, rotary evaporator, mesin giling, botol spray dengan volume $10 \mathrm{ml}$, cawan petri, kertas saring, kapas, spuit $10 \mathrm{ml}$.

\section{Pembuatan Ekstrak Etanol Daun Sirih Merah (Piper crocatum)}

Daun sirih merah dicuci dengan air mengalir dan didiamkan selama semalam. Selanjutnya dipotong kecil - kecil dan dikeringkan dengan cara diangin - anginkan dalam ruangan, tidak terkena sinar matahari secara langsung selama 3 hari. Daun diangin-anginkan hingga terbentuklah simplisia. Simplisia dihaluskan hingga menjadi serbuk dengan cara digiling. Serbuk yang diperoleh kemudian diekstraksi dengan cara maserasi menggunakan pelarut etanol 96\% selama 3 kali 24 jam, dan diambil filtratnya. Filtrat diupkan pelarutnya menggunakan rotary evaporator dengan suhu $50^{\circ} \mathrm{C}$ dengan kecepatan $40 \mathrm{rpm}$, hingga diperoleh ekstrak daun sirih merah yang kental. Hasil ekstrak kemudian diencerkan menggunakan Tween 80 2\% lalu dilakukan perhitungan sesuai konsentrasi yang telah ditentukan.

\section{Koleksi Sampel Larva B. microplus}

Larva B. microplus didapat dari caplak dewasa betina fase engorged yang berjumlah 5 ekor dan masing-masing ditempatkan di wadah tabung, kemudian dilakukan proses rearing pada caplak hingga didapatkan telur yang dikeluarkan secara berkala. Telur ditunggu hingga menetas menjadi larva kemudian ditunggu kembali hingga larva berumur tujuh hari. Sebanyak 250 ekor larva berumur tujuh hari diambil secara acak, kemudian dibagi ke dalam lima kelompok dan masing-masing kelompok terdiri dari 10 larva B. microplus. Setiap perlakuan terdiri atas lima pengulangan. Kelompok perlakuan terdiri dari K-, K+, $\mathrm{P}_{1}, \mathrm{P}_{2}$, $\mathrm{P}_{3}$.

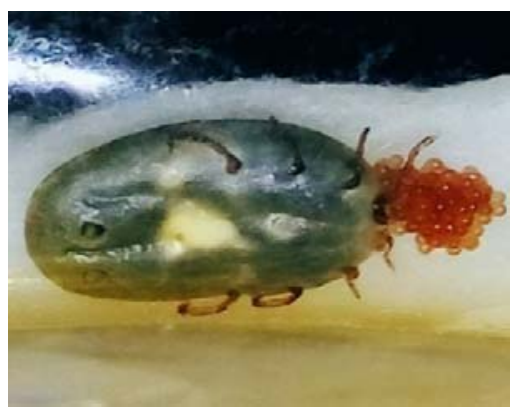

Gambar 1. Caplak B. microplus Betina yang sedang Bertelur.

\section{Pemberian Perlakuan}

Kelompok kontrol negatif disemprot menggunakan Tween 80 2\% tanpa ekstrak daun sirih merah. Kelompok kontrol positif disemprot menggunakan insektisida yang mengandung $10 \mathrm{~g}$ coumaphos. Kelompok perlakuan satu disemprot menggunakan suspensi ekstrak etanol daun sirih merah dan Tween 80 2\% dengan konsentrasi 2,5\%. Kelompok perlakuan dua disemprot menggu-nakan suspensi ekstrak etanol daun sirih merah danTween 80 2\% dengan konsentrasi $5 \%$. Kelompok perlakuan tiga disemprot menggu-nakan suspense ekstrak etanol daun sirih merah dan Tween 8o 2\% dengan konsentrasi $10 \%$. Penyemprotan sebanyak empat kali pada masing-masing kelompok dan ulangannya dilakukan dengan jarak yang sama.

Data yang diperoleh dari penelitian ini dianalisis menggunakan analisis varian 
Journal of Parasite Science

Vol.3 No.1 Maret 2019

eISSN : 2656-5331 , pISSN : 2599-0993

(ANAVA) dua arah atau faktorial dilanjutkan uji Duncan dan untuk mengetahui Lethal Concentration 95 (LC95) maka digunakan metode uji probit. Analisis statistika dilakukan dengan menggunakan program SPSS for windows 22.

\section{Hasil dan Pembahasan}

Hasil pengamatan yang dilakukan terhadap angka mortalitas larva B. microplus berdasarkan pemberian berbagai macam perlakuan dan dihubungkan dengan waktu kematian tercepat yang dibutuhkan dapat dilihat dalam Tabel 1.

Terlihat dari Tabel 1 bahwa pada jam ke dua dengan EDS $10 \%$ menunjukkan hasil yang tidak berbeda nyata dengan pengunaan coumaphos dengan angka mortalitas larva yang tinggi $84 \%$. Hal ini menunjukkan bahwa penggunaan EDS 10\% memiliki tingkat efektivitas yang lebih tinggi dan cepat terhadap mortalitas larva B. microplus bila dibandingkan dengan penggunaan EDS 2,5\% dan 5\%. Maka dari itu dilakukan uji probit terhadap ketiga konsentrasi EDS 2,5\%; 5\%; dan $10 \%$ dalam waktu pengamatan dua jam agar diperoleh $\mathrm{LC}_{50}$ dan $\mathrm{LC}_{90}$. Hasil dari uji probit memberikan

$\mathrm{LC}_{50}$ sebesar $2.700 \mathrm{mg} / 5 \mathrm{oml}$ setara dengan $5,4 \%$ dan LC9o sebesar $5.650 \mathrm{mg} / 5 \mathrm{oml}$ setara dengan $11,3 \%$. Pengujian Lethal Concentration ini bertujuan untuk mengetahui efektivitas ekstrak sirih merah terhadap mortalitas larva terhitung mulai dari $\mathrm{LC}_{50}$ yang menggambarkan jumlah konsentrasi yang dibutuhkan untuk membunuh $50 \%$ populasi sampel dan $\mathrm{LC}_{90}$ yang menggambarkan jumlah konsentrasi yang dibutuhkan untuk membunuh $90 \%$ populasi sampel.

Tingkat mortalitas larva B. microplus mulai jam kesatu hingga jam kelima tergambar dari grafik pada Gambar 1.1 terlihat bahwa terjadi peningkatan mortalitas larva setiap jam dalam perlakuan yang sama, namun pada perlakuan yang berbeda memberikan hasil atau tingkat efektifitas yang berbeda terhadap mortalitas larva B. microplus. Penggunaan insektisida yang mengandung coumaphos telah efektif terhadap mortalitas larva setelah 1 jam penyemprotan dan memberikan hasil optimum pada jam ke 3. Penggunaan EDS 2,5\% dan $5 \%$ juga efektif terhadap mortalitas larva namun belum dapat mencapai optimum hingga jam ke 5, sedangkan pada EDS $10 \%$ telah mencapai titik optimum pada jam ke 5 .

Tabel 1. Rata-rata Prosentase dan Simpangan Baku Pengamatan Mortalitas Larva B. Microplus Berdasarkan Interaksi Perlakuan dan Waktu

\begin{tabular}{|c|c|c|c|c|c|}
\hline \multirow{2}{*}{ Perlakuan } & \multicolumn{4}{|c|}{ Waktu ( jam ke ) } & \multirow[b]{2}{*}{5} \\
\hline & 1 & 2 & 3 & 4 & \\
\hline K- (aquadest+tween 8o) & $8^{\mathrm{a}} \pm 8,36$ & $14^{\mathrm{a}} \pm 5,47$ & $16^{\mathrm{a}} \pm 8,94$ & $18^{\mathrm{a}} \pm 8,94$ & $20^{\mathrm{ab}} \pm 7,07$ \\
\hline $\mathrm{K}+$ coumaphos & $86^{\mathrm{fgh}} \pm 13,41$ & $9^{6^{\mathrm{gh}}} \pm 5,47$ & $100^{\mathrm{h}} \pm 0,00$ & $100^{\mathrm{h}} \pm 0,00$ & $100^{\mathrm{h}} \pm 0,00$ \\
\hline EDS $2,5 \%$ & $16^{\mathrm{a}} \pm 15,16$ & $22^{\mathrm{ab}} \pm 8,36$ & $3^{8^{\mathrm{cd}} \pm 13,03}$ & $50^{d} \pm 7,07$ & $74^{\mathrm{ef}} \pm 23,02$ \\
\hline EDS $5 \%$ & $34^{\mathrm{bc}} \pm 11,40$ & $5 \mathrm{O}^{\mathrm{d}} \pm 7,07$ & $68^{e} \pm 13,03$ & $82^{\mathrm{efg}} \pm 20,49$ & $92^{\mathrm{gh}} \pm 13,03$ \\
\hline EDS $10 \%$ & $68^{e} \pm 14,83$ & $84^{\mathrm{fgh}} \pm 11,40$ & $90^{\mathrm{gh}} \pm 14,14$ & $9^{6^{\mathrm{gh}}} \pm 8,94$ & $100^{\mathrm{gh}} \pm 0,00$ \\
\hline
\end{tabular}

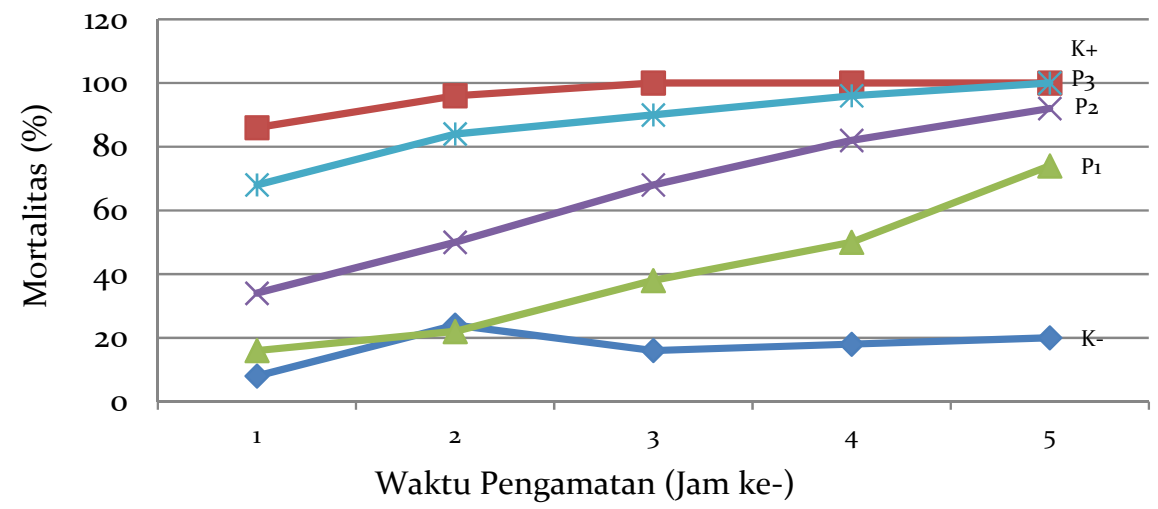

Gambar 2. Grafik Presentase Mortalitas Larva B. microplus K- (Aquadest+tween8o),K+ (Coumpahos), P1 (EDS2,5\%), P2 (EDS 5\%), dan $\mathrm{P}_{3}$ (EDS 10\%). 


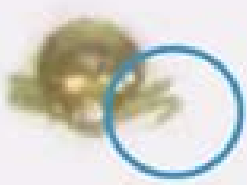

Gambar 3. Larva B. microplus yang Mati (Kaki Larva Menggulung).

Kemampuan ekstrak etanol daun sirih merah untuk mempengaruhi mortalitas larva B. microplus karena adanya bahan aktif tertentu seperti flavonoid, alkaloid, minyak atsiri, dan saponin. Alkaloid juga memiliki fungsi sebagai pestisida nabati (Wempi dan Permadi., 2013), alkaloid memilki kemampuan berikatan dengan DNA hal ini menyebabkan adanya zat diantara DNA yang akan menghambat replikasi DNA akibatnya terjadi gangguan replikasi DNA yang akhirnya akan menyebabkan kematian sel. Kemampuan ekstrak etanol daun sirih merah (Piper crocatum) sebagai larvasida berbanding lurus dengan semakin tinggi konsentrasi ekstrak maka semakin tinggi tingkat efektivitasnya, hal ini sesuai dengan penelitian yang telah dilakukan oleh Wardani pada tahun 2012 mengenai penggunaan ekstrak daun sirih merah terhadap Aeromonas hydropila menunjukkan hasil pada konsentarasi 12,5\% telah mampu menghambat pertumbuhan bakteri, dan pada konsentrasi $25 \%$ dapat mem-bunuh bakteri. Hasil yang didapat secara signifikas mengalami kenaikan antara semakin tingginya konsentrasi sirih merah yang diguna-kan angkat penghambatan pertumbuhan dan kematian bakteri juga semakin tinggi.

\section{Kesimpulan}

Berdasarkan hasil penelitian, maka dapat disimpulkan bahwa, ekstrak etanol daun sirih merah $P$. crocatum efektif terhadap mortalitas larva caplak $B$. microplus secara in vitro dengan menggunakan konsentrasi 10\% mampu menyebabkan kematian larva $100 \%$ pada jam kelimaa dan $\mathrm{LC}_{50}$ ekstrak etanol daun sirih merah dapat dicapai dengan jumlah ekstrak 2.70omg/5oml yang setara dengan $5,4 \%$ dan $\mathrm{LC}_{90}$ dicapai dengan jumlah ekstrak $5.65 \mathrm{omg} / 5 \mathrm{oml}$ yang setara dengan $11,3 \%$.

\section{Daftar Pustaka}

Bamuallim, A.M. 2007. Produksi Peternakan Di Indonesia: Potensi dan Kendala Seminar Nasional Tekhnologi Peternakan dan Veteriner. Hal: 22-24.

Boka, O.M., L. Achi, H. Adakal. A. Azokou, P. Yao, Y.G. Yapi, M. Kone, K. Dagnogo, and Y.Y. Kaboret. 2017. Review of Cattle Ticks (Acari, Ixodida) in Ivory Coast and Geographic Dostribution of Rhipicephalus (Boophilus) microplus, an Emerging Tick in West Africa. Page: 2-5.

Fatrowie, A.F. 2015. Perbedaan Toksisitas Ekstrak Daun Sirih Hijau dengan Berbagai Jenis Pelarut terhadap Mortalitas Larva Nyamuk Aedes aegypti .L.[Karya Tulis Ilmiah]. Fakultas Keguruan dan Ilmu Pendidikan. Universitas Jember.

Hendrix, C.M and E. Robinson. 2006. Diagnostic Parasitology for Veterinary Technicians. 3th Ed. Mosby Inc. an affiliate Elsevier Inc.

Jongejan, F dan G. Uilenberg. 2004. The Global Importance Tick. J Agr Res. 19: 689-710.

Neldawati, R., dan Gusnedi. 2013. Analisis Nilai Absorbansi dalam Penentuan Kadar Flavonoid untuk Berbagai Jenis Tanaman Obat. Pillar of Physics. Vol 2: 76-83.

Wahyuwardhani, S. 1995. Pengaruh Perkembangan Tubuh Caplak Boophilus microplus Betina Dewasa terhadap Fertilitas Telurnya. Balai Penelitian Veteriner. 1(1): 43-47.

Wardhana, A.H., A. Husein, dan J. Manurung. 2005. Efektifitas Ekstrak Biji Srikaya (Annona squamosa L.) dengan Pelarut Air, Metanol, dan Heksan terhadap Mortalitas Larva Caplak Boophilus microplus secara In Vitro. Balai Penelitian Veteriner. 10(2): 134-140.

Wardani, R.K. 2012. Uji Efektifitas Daun Sirih Merah (Piper crocatum) terhadap Aeromonas hydropila. [Skripsi]. Fakultas Perikanan dan Kelautan. Universitas Airlangga.

Wempi, I.G dan D.S. Permadi. 2013. Keaneka ragaman Tanaman Obat sebagai Larvasida dalam Upaya Pengendalian Vektor Demam Berdarah Dengue (DBD). Jurnal Sains dan Teknologi Lingkungan. 5(1): 1220. 